\title{
Socially Responsible Leadership Capacity among Student Leaders
}

\author{
K. Faridah Mydin, Muhammad Syawal Amran \\ Faculty of Education, Universiti Kebangsaan Malaysia, Bangi, Malaysia \\ Email: faridah_mydin@ukm.edu.my
}

How to cite this paper: Mydin, K. F., \& Amran, M. S. (2019). Socially Responsible Leadership Capacity among Student Leaders. Creative Education, 10, 2955-2967. https://doi.org/10.4236/ce.2019.1012220

Received: October 21, 2019

Accepted: November 26, 2019

Published: November 29, 2019

Copyright $\odot 2019$ by author(s) and Scientific Research Publishing Inc. This work is licensed under the Creative Commons Attribution International License (CC BY 4.0).

http://creativecommons.org/licenses/by/4.0/

\section{c) (i) Open Access}

\begin{abstract}
Student leaders are key agents of social change, capable of facing complex challenges. There is widespread awareness at the university level to develop socially responsible leadership among students' leaders. The Social Change Model of Leadership Development (SCM) has been specifically developed for higher education to increase students' self-knowledge, to develop leadership competency, openness and accountability that would result in positive social change. The purpose of this study was to discover the impacts that student governance involvement and leadership activities have on students' opinion about leadership for social change. Qualitative method through semi-structured interview was used to explore student perceptions of their leadership talent, the congruency between thoughts and action, and finally their commitment to the task. A total of 10 student leaders voluntarily participated in this study. They were selected through purposive sampling. The interview protocol was structured based on three core values in SCM: Individual, Group, and Community. Interview sessions were recorded, transcribed and then analysed using the thematic analysis method. Overall, the results show that the students directly and indirectly practised the values in the SCM model. Based on these results, this study therefore proposed that the university includes the SCM model in their student leadership training. This is crucial so that students would gain knowledge of the fundamental values in SCM in order to be more responsive to social issues.
\end{abstract}

\section{Keywords}

Student Leadership, Student Governance, Social Change Model, Malaysia

\section{Introduction}

Learning experience in higher education has tremendous impact on student self-development. The purpose of higher education is not only to prepare stu- 
dents for entry into the work force but also to produce individuals who possess excellent transferable skills and appropriate graduate attributes. Thus, the development of a well-rounded student learning experience remains a central focus of universities (Mydin \& Rahman, 2018; Selamat et al., 2012). This can be achieved through creating a positive learning environment that helps students to manage and develop their talents as well as build good personality. In this context, providing students an environment that offers students the opportunities for intellectual development while also actively promoting the benefits of involvement in wider co-curriculum activities is crucial.

The development of leaders and building of leadership capacity among students through co-curriculum activities have become a common feature at universities all around the world (Foreman \& Retallick, 2016). According to Larson, Wilson, \& Mortimer (2002), students are potential future leaders and universities are seen as the perfect training ground to prepare them with the knowledge and skills necessary for later use in the workplace and society. Leadership skills learned and practised through experiential learning activities, leadership courses, conferences, academic courses, associations and student organisations help them to build their own character strengths.

At university, the Student Representative Council (SRC) is one of the established organisations designed to develop and strengthen students' leadership skills. The SRC serves as the intermediary body between the students and the university managers. The SRC is committed towards responding to students' concern and needs with the intention of improving student-learning satisfaction, facilities and services. At the same time, the SRC also has relations with external institutions including ministries, government departments, non-governmental organisations and communities. This means that the roles of the SRC encompass those within the campus as well as those outside the campus. Apart from enhancing individual leadership skills at the university level, SRC is also involved with issues at the community level, and this has been associated with increased public involvement and volunteering activities for university students.

In this regard, the present article examines the effects of student participation in SRC activities with respect to social responsibility. Socially responsible leadership is a term commonly used in business and cooperation to assess their contribution towards uplifting community well-being and environment (Komives, 2011). Nowadays, this concept has been widely used and interpreted within the context of organisations, for example at universities where social responsibility among students is encouraged through their training programmes and also through voluntary programmes (Jabbour, 2010, Pollock, Horn, Costanza, \& Sayre, 2009). Research suggests that student involvement in community programmes increase their leadership skills, as well as nurture a sense of ownership and responsibility (Foster-Fishman et al., 2007). However, little research has been conducted on assessing the impact of SRC leadership experiences on students' social responsibility. Thus, by adopting the Social Change Model of Leadership Development (Higher Education Research Institute (HERI), 1996), this 
study sought to understand how students' participation in student governance leadership activities contributes to the development of the individual values. The Social Change Model of Leadership Development provides insights into the leadership values that must exist within the individual and team work in developing students and communities (Astin, 1996; Roberts, 2007).

Using an exploratory qualitative research design, this study addressed the following research question: how has students' involvement in various leadership programmes develop the individual values in the SCM model? This paper is organised as follows: it begins by discussing the literature on student governance at university which is then followed by a discussion on the SCM model. Next, the study's methodology is presented, followed by a section on the analysis of the qualitative findings. Finally, in the concluding section, conclusions are drawn, and issues worthy of further research are identified.

\subsection{Student Participation in University Governance}

Institutions of higher education have great responsibility to groom future leaders with strong character (Skalicky et al., 2018). A substantial body of research supports that student involvement in various programmes and activities across university has tremendous impact on their leadership skills (Foreman \& Retallick, 2016; Stephens \& Beatty, 2015). Student governance for example, is specifically designed to develop leadership capabilities among students. Apart from significant growth in leadership skills, these leadership activities have great impact on student civic responsibility, multicultural awareness, personal and societal values (Cress, Astin, Zimmerman-Oster, \& Burkhardt, 2001).

Leadership is defined based on various perspectives, context and backgrounds. Post-industrial perspectives have conceptualised leadership as open, transformative, flexible, and collective in creating change (Allen \& Cherry, 2000; Gill, 2012). Meanwhile, according to Hoy \& Meisel (2008), leadership that emphasises on collective and value-based elements is important in promoting positive social change. Namely, leadership is seen as a process of sharing between leaders and followers rather than individualistic. According to Blackwell, Cummins, Townsend, \& Cummings (2007), these elements need to be applied in the new generation through formal or informal leadership programmes, in preparation for future challenges.

Student involvement in university governance is a manifestation of the democratic process where students can actively contribute to the management of their university (Lizzio \& Keithia Wilson, 2009). It is an example of how the university manifests its objective of producing leaders at the university level. As one of the important stakeholders, student governance acts as the representatives that raise and voice academic and campus issues at the managerial level and find practical solutions. The concept of power sharing and interdependence is essential in the development of effective university governance.

As one of most reputable student organisations, many universities have widened student governance roles to include a various range of responsibilities and 
activities that does not only focus on activities in campus but also those that have significant impact on the social-community (Owen, 2012). Activities such as volunteerism, debates, and public education provide students with more meaningful leadership experiences that not only enhance their leadership capacities but also allow them to acquire and develop new skills that allow them to be socially responsible. In the United State universities for example, they actively promote various programmes and learning opportunities that encourage proactive role among students so that they would be making positive change and improving their society. Empowering students to be social change agents is one of main objectives emphasised in the social change model of leadership development. Komives et al. (2011) describe social change as a process that emphasises awareness and responsibility of individuals towards others.

\subsection{Social Change Model of Leadership Development}

The Social Change Model of Leadership Development (Higher Education Research Institute [HERI] 1996) describes leadership as a purposeful, collaborative, value-based process that results in positive social change (HERI, 1996). This model was specifically created for students in higher education to improve their capacities to collaborate as a team and making positive change in society over their lifetime (HERI, 1996). According to Dooley \& Shellogg (2016), SCM is one of the well-established models that has been developed to guide leadership development among college students. The key assumptions in the SCM model are leadership brings change to others and the society, is collectivist, emphasises on the process rather than the position of being a leader and is based on values (Komives \& Wagner, 2012). In this respect, each individual is seen to have the capacity to lead, depending on the level of readiness and openness of the individual. The SCM encompasses seven values which are categorised into three domains: individual values (consciousness of self, congruence, and commitment), group process values (collaboration, common purpose, and controversy with civility), and community/societal values (citizenship) (Dixon, Wales, Pennington, \& Calega, 2018; HERI, 1996; Komives \& Wagner, 2017). The centrality of this model is individual self-knowledge and capacity to engage others in collaborative work. The definition for each of these values is presented in Table 1.

Students who are involved in student governance automatically position themselves as a person with responsibility over others. This is aligned with the definition of student leader by Astin who describes " a highly involved student is one who, for example, devotes considerable energy to studying, spends a lot of time on campus, participates actively in student organizations, and interacts frequently with faculty members and other students" (Astin, 1984: p. 297). Student governance provides valuable platform for students to develop core values in SCM whether explicitly or implicitly through a variety of programmes and activities that they organise. Skills and competencies used in the process of organising and managing activities are considered as part of experiential learning 
Table 1. Definition of core-values of the social change model.

\begin{tabular}{|c|c|}
\hline Consciousness of Self & $\begin{array}{l}\text { Awareness of the beliefs, values, attitudes, and emotions that motivate one } \\
\text { to takeaction. }\end{array}$ \\
\hline Congruence & $\begin{array}{l}\text { Thinking, feeling, and behaving with consistency, genuineness, } \\
\text { authenticity, and honesty towards others; actions are consistent with most } \\
\text { deeply held beliefs and convictions. }\end{array}$ \\
\hline Commitment & $\begin{array}{l}\text { The psychic energy that motivates the individual to serve and that drives } \\
\text { the collective effort; implies passion, intensity, and duration, and is } \\
\text { directed towards both the group activity as well as its intended outcomes. }\end{array}$ \\
\hline Collaboration & $\begin{array}{l}\text { To work with others in a common effort; constitutes the cornerstone value } \\
\text { of the group leadership effort because it empowers self and others through } \\
\text { trust. }\end{array}$ \\
\hline Common Purpose. & $\begin{array}{l}\text { To work with shared aims and values; facilitates the group's ability to } \\
\text { engage in collective analysis of issues at hand and the task to be } \\
\text { undertaken. }\end{array}$ \\
\hline $\begin{array}{l}\text { Controversy } \\
\text { with Civility }\end{array}$ & $\begin{array}{l}\text { Recognises two fundamental realities of any creative group effort: that } \\
\text { differences in viewpoint are inevitable, and that such differences must be } \\
\text { aired openly, but with civility. Civility implies respect for others, a } \\
\text { willingness to hear each other's views, and the exercise of restraint in } \\
\text { criticising the views and actions of others. }\end{array}$ \\
\hline Citizenship & $\begin{array}{l}\text { The process whereby an individual and the collaborative group become } \\
\text { responsibly connected to the community and the society through the } \\
\text { leadership development activity. To be a good citizen is to work for } \\
\text { positive change on behalf of others and the community. }\end{array}$ \\
\hline Change & $\begin{array}{l}\text { The ability to adapt to environments and situations that are constantly } \\
\text { evolving, while maintaining the core functions of the group. }\end{array}$ \\
\hline
\end{tabular}

Source: HERI, 1996.

(Layfield et al., 2000). According to Kuh (2008), skills of teamwork, communication and problem solving are developed through well-designed experiential learning environments.

Student leaders who are actively engaged in student's activities at campus, community and professional bodies are more likely to have higher tendency to experience situations that increase their development of the seven core leadership values in the social change model. Most existing studies on SCM framework and student governance at university have been undertaken in the Western contexts where students have strong understanding of each core value. This is different in the Malaysian setting where these values are not clearly explained to the students. It is therefore important to understand student leadership experiences in student governance, and these experiences related to core values in SCM.

\section{Methodology}

In this study, the qualitative approach was taken to explore student governance leadership experience based on SCM. This approach allows for an in-depth investigation of what students perceive as important from their perspective in relation to their leadership activities. Data was gathered through in-depth, semi-structured interviews. This study was conducted at one of the public universities in the 
Klang Valley, Selangor. A total of 10 study participants who are student leaders were selected using the purposive sampling method. The semi-structured interview method was used to obtain the data. Interview protocols were developed based on the individual, group and community values indicators in the social change model. Interview sessions were conducted in campus, lasting between 45 to 60 minutes. All interviews were audiotaped and transcribed verbatim. All data were analysed using the thematic approach.

\section{Findings and Discussion}

This section presents results from the data collected through the semi-structured interviews. The data were analysed based on three-core themes within the SCM model: Individual, Group and Social. Overall, participants in this study appeared to understand themselves, managing activities well through shared values and understand their role towards the wellbeing of the community.

Individual Values. Individuals' ability to identify their own personal qualities and abilities to self-reflect on their thoughts and actions has significant impact on how they work collectively to produce positive changes. According to Komives (2007), understanding one's "self" is significant to one's ability to function in the other values in SCM. Participants' previous leadership experiences at the secondary school and college level intricately contribute to their leadership identity development. They considered it as an influential experiential learning which helps them to develop some knowledge and skills of being a leader, and therefore making them feel more confident to take further leadership role in student governance. Participation in leadership activities such as being a school prefect, chairperson of school clubs, or being involved in student governance at college are among the early exposure in leadership activities that had helped them to identify their personal qualities. As stated by one of the participants:

"My early involvement in student governance at college was meaningful experiences which help me to identified my talent and qualities as a leader... and this is the starting point why I am interested in becoming a leader"

Several personal traits which reflect participants strength and qualities can be identified from the interviews, for example "I like to try new things", "I like to help others" and "I like to be a leader". Apart from their own understanding of themselves, participants in this study also expressed that their personal qualities and strength area reflection of others such as family members and peers. For example, some of participants' family members hold a variety of position as leaders in the community, political body and at the workplace. According to the participants, their parents' character is indirectly embedded in them through communication, behaviour and thinking. For example, Zif shared how his mother always encouraged him to be involved in student activities as she sees his talent:

"My mother always said that I have a talent to be a leader ... so she always shared her experience, teach me how to communicate and expressed idea effec- 
tively."

The influence of others was also evident in Lan's stories. According to him, the senior at university have contributed greatly to his leadership identity development during the early stages. As commented by Lan, his senior is an important person who encouraged him to be involved in student governance. This all started when he was involved in one of his seniors' project at the residence hall. The influence of his senior who believed in his ability was an important factor that helped him to become a student leader. As Lan stated:

"...my senior helped a to realize my hidden potential to lead, he always guide me, and give me suggestion when I have any conflicting issues. I also learned a lot from observing him, his character, thinking and how he manage one activity."

For many of these students, encouragement from others helped them to understand their own self and enabled them to gain a sense of confidence to become involved in opportunities of leadership. In this case, students not only understand and discover about themselves, but more importantly, they became aware of how they could make meaningful impact on others. In this context, a good leader also helps to identify potential future leaders (Rossi, 2001).

Once an individual understands himself or herself and his or her role as a leader, he or she is able to collaborate with others to create social change. For example, one participant stated that the desire to bring changes and make a difference is more important compared to the position held. This is clear in Mi's interviews when he described:

"I want student at campus realized that they have a place where they can come and discuss about the problem or any difficulties... I want them feel valued, supported and involved."

This participant is clear about their position as a student leader and their aspiration to create quality learning experiences in campus (Mydin, 2017). For example, one the participants shared his experience of tackling water shortage problem at the student residence halls. According to him, this is a basic need of the students that requires promptattention from the management. Together with his team, he put his effort into finding a solution to the problem by preparing paperwork and meeting up with the top management. Even though the issue could not be resolved quickly, his desire to bring change to the problem faced by the students is something noble. In this case, the individual commitment towards pursuing their responsibility is clear within all participants.

The individual values portrayed by these participants resonate with the three core values of individuals in the SCM model. Previous leadership experiences allowed them to see their role as a leader clearly and their capacity to work with others to bring changes. This is strengthened by the influence of peers and family members (Hamjah et al., 2019). The participants' meaningful involvement and experiential learning is closely related to their personal values and interest as well as desire to bring changes to the campus community. 
Group Values. Individuals' personal qualities are associated with their attitude towards working in a team. Effective leadership requires individuals who possess teamwork skills as well as collaborative and cooperative skills. According to Komives et al., (2011), collaboration concerns "how people relate to each other" and the process of "developing common visions, goals, and purpose" (Komives \& Wagner, 2009). The respondents in this study admitted to the challenges of working with other members who are of different identities and from diverse background. As student representatives, these students have to deal with students who come from different ethnicity, race, gender, personality, and academic background. According to the participants, the key to effectively manage this diversity is through building trust and respect towards each other during the meetings. As shared by one participant, "I know I need to be open minded to any feedback or critiques from other students". The same opinion was also voiced by another participant, Liza who stated:

"I know I am a type of person don't like to stick on my own decision, for me I should considered other people suggestion and ideas which may more practical... than what I can suggest..."

In this context, being open minded and open to differences in opinions are an important core value in the SCM model which helped the participants to collaborate more effectively towards ensuring the success of the programmes that they were involved in. In this respect, what was more important to the participants is to cooperate well with other members in the group for the common good. As stated by one of the participants:

"I could not denied sometimes I feel stress and pressure when some of the members critique my capability to complete some task...in this situation I try my best to stay clam by listening to him...even though I think his suggestion doesn't make sense".

In this case, the participant believes that being assertive and diplomatic in his speech and in his actions are more pertinent in dealing with the negative interaction with other group members. Hence, it is clear that what is more important for these participants is to stay focused and to get the work done rather than create a struggle or altercation between them.

The importance of having strong connection between group members also appeared in Shah's description of his experience of organising programmes and events for his university's graduation ceremony. According to Shah, the graduation event necessitated a tremendous amount of effort and time being invested by him and his team as they wanted to make the event impactful and successful. Additionally, Shah also mentioned that having to work with other board members who were also leaders of their own committees was a challenge for him. As he mentioned, "... you need to be personally and emotionally strong and also believed on others capability to take responsibility". By subscribing to this value, he was able to assign responsibilities among the team members so that everyone knew each of their roles. 
Based on the analysis, the individual leadership paradigm helped to facilitate the participants' leadership at the group level. As described by the participants, working as a team helped them to run their programmes successfully by drawing upon each other's unique strengths. The ability to trust other people's talents and ability is essential to achieve the required outcome. Participation in collaborative group processes offers experiences and feedback that enhance a participant's leadership at the individual level and enables them to be more aware about themselves by working as a group. This experiential learning experience helps them to improve their emotional intelligence and nurture inter- and intrapersonal skills, persuasion and influencing skills when dealing with differences (Majee, Long, \& Smith, 2012).

Community Values: Interdependence between individual and group values would facilitate positive social change at the community level. Involvement in the community through certain activities is considered as a practical opportunity for student leaders to apply their leadership learning in the community surrounding them (Dugan \& Komives, 2007). Citizenship as a social value helps individuals become "responsibly connected to the community and society" (Wagner, 2006: p. 9). This part of the data analysis therefore explores and discusses the participants' leadership experiences while being involved in community-based projects.

Overall, all the participants remarked that they have had some experience organising and participating in community-based projects whether directly or indirectly. Among the community-based projects organised by these participants were leadership camp, motivation camp, food bank project for the homeless and public health. For example, Shah's experience of organising leadership camp for lower secondary students in arural secondary school is considered as a meaningful contribution to the society. According to Shah, the two-day programme helped to provide the rural students exposure to leadership as well as increase their awareness of their qualities, strengths and potential to become a leader in the future. Shah elaborated that even though the programme was scheduled for only two days, he and his team felt overwhelmed after receiving positive feedback from the students and the teachers. Within the short period of time, they had managed to provide meaningful and impactful experiences to the rural students. In his reflection, Shah said university students need to become agents of change, and that they should become a role model to this disadvantaged community. As a future teacher, Shah seems to emotionally enjoy the experience and feel satisfied, and eager to continue this kind of programme in the future. As he said:

"My experience involved with this school leadership program give me different perspectives and view about being a leader as also future teacher and the need to help the disadvantage kids... and I will continue with this kind programme in future..."

Another participant, Zai shared his successful story of organising an activity to support the homeless by providing them free food and clothes. According to 
Zai, this programme was carried out in collaboration with anon-governmental organisation (NGO) where he was one of the members. Through Zai's strong connection with the NGO and the strong support from his team, they managed to collect money and clothes which were donated by the community within and around the campus to be distributed to the homeless people. According to him, through this activity, he managed to increase social awareness among students and the community about the importance of helping the less privileged people in the society. His strong determination and the great support and commitment that he received from the team members resulted in a successful and impactful event. According to Zai, he will continue with this kind of activity even after graduating as he explained:

"I enjoy doing this volunteering job, I learn many thing... this kind of experience give me different perspectives and become more socially responsible citizens".

In this context, his leadership role not only affected his individual perception and values but also others who participated in his activity.

Additionally, other projects such as motivation camp at school and public health programme for the society are among the activities performed by these participants to show their commitment and involvement towards the society. Within the SCM model, this experiential learning through interaction and involvement with people outside the campus helped the participants to develop their sense of social awareness and citizenship (Eyler, 2002). Involvement in community-based activities benefits students psychosocially resulting inincreased self-esteem, improved self-concept, and development of greater sense of social responsibility (Harkins et al., 2018; Celio et al., 2011; Mujani \& Muttaqin, 2012; Perin, 2011).

\section{Conclusion}

Overall, participation in student governance is a positive and motivating experience. These students persistently performed excellent leadership values through shared goals, collaboration, strong sense of commitment and responsibility, and open communication. Clearly, these experiences have had a significant impact on how they view themselves as an individual, within a group and in the community. What they have learnt from their leadership at university makes them clearer about their roles and about the perception that leadership is a collective process and not a one man show. Furthermore, even though the student leaders in the context of this study were clearly not given any instruction about the social change model of leadership development, their experiences and their views were focused towards socially responsible leadership. This leadership experience not only changed how they view themselves, it also changed their views in relation to how their leadership would have an impact on others, or the society in general. It is therefore important that the characteristics of socially responsible leadership in the SCM model are instilled among student leaders at university in 
a more lucid and clear manner in order to help them understand the characteristics and skills that they need to perform it more fittingly.

\section{Funding}

This research was partially supported by grant received from the Faculty of Education, Universiti Kebangsaan Malaysia code GG-2019-042 and PP-FPEND 2019.

\section{Conflicts of Interest}

The authors declare no conflicts of interest regarding the publication of this paper.

\section{References}

Allen, K., \& Cherry, C. (2000). Systemic Leadership: Enriching the Meaning of Our Work. Lanham, MA: University Press of America.

Astin, A. W. (1984). Student Involvement: A Developmental Theory for Higher Education. Journal of College Student Personnel, 25, 297-308.

Astin, H. (1996). Leadership for Social Change. About Campus, 1, 4-10. https://doi.org/10.1002/abc.6190010302

Blackwell, C., Cummins, R., Townsend, C. D., \& Cummings, S. (2007). Assessing Perceived Student Leadership Skill Development in an Academic Leadership Development Program. Journal If Leadership Education, 6, 39-58.

https://doi.org/10.12806/V6/I1/RF1

Celio, C. I., Durlak, J., \& Dymnicki, A. (2011). A Meta-Analysis of the Impact of Service Learning on Students. Journal of Experiential Education, 34, 164-181. https://doi.org/10.1177/105382591103400205

Cress, C. M., Astin, H. S., Zimmerman-Oster, K., \& Burkhardt, J. C. (2001). Developmental Outcomes of College Students' Involvement in Leadership Activities. Journal of College Student Development, 42, 15.

Dixon, D. P., Wales, A. M., Pennington, J. R., \& Calega, S. (2018). Social Change Model of Leadership Development: A 4-Year Program. Management Teaching Review, 4, 138-147. https://doi.org/10.1177/2379298118810845

Dooley, J., \& Shellogg, K. (2016). Social Change Model of Leadership Development: A 20-Year Legacy and Future Considerations. Campus Activities Programming, 49, 20-25.

Dugan, J. P., \& Komives, S. R. (2007). Developing Leadership Capacity in College Students: Findings from a National Study. A Report from the Multi-Institutional Study of Leadership. College Park, MD: National Clearinghouse for Leadership Programs.

Eyler, J. (2002). Reflection: Linking Service and Learning-Linking Students and Communities. Journal of Social Issues, 58, 517-534. https://doi.org/10.1111/1540-4560.00274

Foreman, E. A., \& Retallick, M. S. (2016). The Effect of Undergraduate Extracurricular Involvement and Leadership Activities on Community Values of the Social Change Model. NACTA Journal, 60, 86-92.

Foster-Fishman, P. G., Cantillon, D., Pierce, S. J., \& Van Egeren, L. (2007). Building an Active Citizenry: The Role of Neighborhood Problems, Readiness, and Capacity for Change. American Journal of Community Psychology, 39, 91-106. 
https://doi.org/10.1007/s10464-007-9097-0

Gill, R. (2012). Theory and Practice of Leadership. Thousand Oaks, CA: Sage

Hamjah, S. H., Zur Raffar, I. N. A., Mohamad, R. R., \& Mohd, K. Z. (2019). Adolescent's Perceptions of Father's Leadership Style in the Family. The Journal of Social Sciences Research, 5, 284-290. https://doi.org/10.32861/jssr.52.284.290

Harkins, D. A., Kozak, K., \& Ray, S. (2018). Service-Learning: A Case Study of Student Outcomes. Journal of Service-Learning in Higher Education, 8, 1-14.

Hoy, A., \& Meisel, W. (2008). Civic Engagement at the Center: Building Democracy through Integrated Co-Curricular and Curricular Experiences. Washington DC: Association of American Colleges and Universities.

Jabbour, C. J. C. (2010). Greening of Business Schools: A Systematic View. International Journal of Sustainability in Higher Education, 11, 49-60. https://doi.org/10.1108/14676371011010048

Komives, S. R. (2011). College Student Leadership Identity Development. In S. E. Murphy, \& R. J. Reichard (Eds.), Early Development and Leadership: Building the Next Generation of Leaders. New York: Psychology Press/Routledge.

Komives, S. R., \& Wagner, W. (2009). Leadership for a Better World: Understanding the Social Change Model of Leadership Development. A Publication of the National Clearinghouse for Leadership Programs. San Francisco, CA: Jossey-Bass.

Komives, S. R., Dugan, J., Owen, J. E., Slack, C., \& Wagner, W. (2011). Handbook for Student Leadership Development (2nd ed.). A Publication of the National Clearinghouse for Leadership Programs. San Francisco, CA: Jossey-Bass.

Komives, S., \& Wagner, W. (2017). Leadership for a Better World: Understanding the Social Change Model of Leadership Development (2nd ed.). San Francisco, CA: Jossey-Bass.

Kuh, G. D. (2008). High-Impact Educational Practices: What They Are, Who Has Access to Them, and Why They Matter. Report from the Association of American Colleges and Universities.

Larson, R. W., Wilson, S., \& Mortimer, J. T. (2002). Conclusions: Adolescents \& Apes; Preparation for the Future. Journal of Research on Adolescence, 12, 159-166. https://doi.org/10.1111/1532-7795.00029

Layfield, K. D., Radhakrishna, R. B., \& Andreasen, R. J. (2000). Self-Perceived Leadership Skills of Students in Leadership Programs in Agriculture Courses. The Journal of Southern Agricultural Education Research, 50, 62-68.

Lizzio, A., \& Wilson, K. (2009). Student Participation in University Governance: The Role Conceptions and Sense of Efficacy of Student Representatives on Departmental Comités. Studies in Higher Education, 34, 69-84. https://doi.org/10.1080/03075070802602000

Majee, W., Long, S., \& Smith, D. (2012). Engaging the Underserved in Community Leadership Development: Step Up to Leadership Graduates in Northwest Missouri Tell Their Stories. Community Development, 43, 80-94. https://doi.org/10.1080/15575330.2011.645049

Mujani, W. K., \& Muttaqin, A. (2012). Female Student Involvement in Campus Leadership. Advances in Natural and Applied Sciences, 6, 1385-1388.

Mydin, K. F. (2017). Underpinning Excellence in Higher Education: Exploring Self-Regulatory Skills of High Performing Academic Students. Advances in Social Sciences Research Journal, 14, 120-130.

Mydin, K. F., \& Rahman, R. S. A. (2018). Openness to New Learning Experience and 
Challenges: A Study of Success Student. Journal of Advance Research in Dynamical \& Control Systems, 10, 1726-1731.

Owen, J. E. (2012). Findings from the Multi-Institutional Study of Leadership Institutional Survey: A National Report. College Park, MD: National Clearinghouse for Leadership Programs.

Perin, D. (2011). Facilitating Student Learning Through Contextualization. Community College Research Center, Working Paper No. 29, New York: Columbia University.

Pollock, N., Horn, E., Costanza, R., \& Sayre, M. (2009). Envisioning Helps Promote Sustainability in Academic: A Case Study at the University of Vermont. International Journal of Sustainability in Higher Education, 10, 343-353. https://doi.org/10.1108/14676370910990693

Roberts, D. C. (2007). Deeper Learning in Leadership: Helping College Students Find the Potential Within. San Francisco, CA: Jossey-Bass.

Rossi, A. S. (2001). Caring and Doing for Others: Social Responsibility in the Domains of Family, Work, and Community. Chicago, IL: University of Chicago Press.

Selamat, J., Ismail, K. M., Aiyub, K., Lukman, Z. M., Ariffin, K., Rajikan, R., Awang, A., Abd Rahim, M. H., \& Derahim, N. (2012). Learning Contract: New Approach in Assessing and Evaluating Students' Co-Curricular Activities. Social Sciences, 7, 522-529. https://doi.org/10.3923/sscience.2012.522.529

Skalicky, J., Pedersen, K. W., van der Meer, J., Fuglsang, S., Dawson, P., \& Stewart, S. (2018). A Framework for Developing and Supporting Student Leadership in Higher Education. Studies in Higher Education, 1-17. https://doi.org/10.1080/03075079.2018.1522624

Stephens, C. M., \& Beatty, C. C. (2015). Leading and Thriving: How Leadership Education Can Improve First-Year Student Success. Journal of Leadership Education, 14, 119-131. https://doi.org/10.12806/V14/I3/T1

Wagner, W. (2006). The Social Change Model of Leadership: A Brief Overview. Concepts \& Connections, 15, 9. 